\title{
Pengurangan Resiko Penyebaran Covid-19 pada Jamaah Sholat Jumat di Masjid Kota Blitar Melalui Program Masker Gratis
}

\author{
Diana Elvianita Martanti ${ }^{1^{*}}$, Ahmad Yufron ${ }^{2}$, Suprianto ${ }^{3}$ \\ ${ }^{1}$ Akuntansi, Universitas Islam Balitar, Jl. Majapahit No.2- 4, Kota Blitar, Indonesia, 66137 \\ ${ }^{2}$ Teknik Sipil, Universitas Islam Balitar, J1. Majapahit No.2- 4, Kota Blitar, Indonesia, 66137 \\ ${ }^{3}$ Manajemen, Universitas Islam Balitar, Jl. Majapahit No.2- 4, Kota Blitar, Indonesia, 66137
}

Correspondence: dianaelvianitamartanti@unisbablitar.ac.id

Received: 30 Juni 2021 - Revised: 01 Agustus 2021 - Accepted: 16 Agustus 2021

\begin{abstract}
Abstrak. Di wilayah Blitar terdapat beberapa masjid yang masih aktif melaksanakan kegiatan sholat berjamaah meskipun sedikit terganggu karena adanya pandemi. Pemerintah Kota Blitar memperbolehkan adanya kegiatan sholat berjamaah di Masjid akan tetapi harus tetap menerapkan protokol kesehatan. Tujuan dari pengabdian ini adalah untuk mencegah dan memutus mata rantai penularan Covid-19 di Masjid Kota Blitar. Metode kegiatan dalam pengabdian ini adalah sosialisasi, pelaksanaan dan evaluasi. Hasil dari kegiatan adalah terlaksananya kegiatan sosialisasi pencegahan penularan covid-19 di Masjid Kota Blitar dan pemberian masker gratis sebanyak 100 buah kepada jamaah sholat jumat terutama bagi yang jamaah yang tidak menggunakan masker agar kedepannya ketika akan melakukan kegiatan baik kegiatan ibadah maupun lainnya dapat menggunakan masker.
\end{abstract}

Kata kunci: Jamaah sholat Jumat, Masjid, masker gratis

Citation Format: Martanti, D.E., Yufron, A. \& Suprianto. (2021). Pengurangan Resiko Penyebaran Covid-19 pada Jamaah Sholat Jumat di Masjid Kota Blitar Melalui Program Masker Gratis. Prosiding Seminar Nasional Abdimas Ma Chung (SENAM), 106-111. 


\section{PENDAHULUAN}

Coronovirus Disease 2019 (COVID-19) merupakan penyakit yang perkembangannya sangat cepat dan mewabah di beberapa negara sehingga pada tanggal 11 Maret 2019, kasus ini ditetapkan sebagai kejadian pandemic global oleh World Health Organization. Covid19 merupakan infeksi virus baru yang mengakibatkan terinfeksinya 90.308 orang pertanggal 2 Maret 2020. Virus ini bermula di Wuhan,China pada 31 Desember 2019. Virus yang merupakan virus RNA strain tunggal positif ini menginfeksi saluran pernapasan (Yuliana, 2020).

Indonesia merupakan salah satu negara dengan jumlah kasus terkonfirmasi yang cukup tinggi, yakni hingga tanggal 02 Juni tercatat sebanyak 27.549 kasus. Melalui Kementerian Kesehatan, pemerintah Indonesia menginstruksikan pelaksanaan upaya pencegahan COVID-19 sebagaimana yang direkomendasikan oleh WHO, yaitu kesadaran dan kepatuhan dalam penggunaan masker ketika di luar rumah dan Cuci Tangan Pakai Sabun (CTPS) (Kemenkes RI, 2020).

Salah satu anjuran untuk mencegah terjadinya semakin menyebar wabah Covid-19 adalah dengan menggunakan masker. Menurut ECDC (2020) masyarakat dianjurkan menggunakan masker di luar rumah. Jenis masker yang dapat digunakan adalah masker kain yang merupakan salah satu contoh dari masker non medis atau disebut pula dengan masker komunitas yang merupakan penutup muka buatan sendiri atau komersialyang terbuat dari kain. Meskipun masker non medis tersebut bisa pula dari tekstil lain atau bahan lain seperti kertas yang dapat digunakan oleh masyarakat yang bukan termasuk pemberi atau petugas pelayanan kesehatan.

Meningkatnya penyebaran Covid-19 di Blitar mengakibatkan sejumlah kegiatan masyarakat di tiadakan untuk sementara, salah satunya yaitu kegiatan jamaah sholat di Masjid. Di masa Pandemi kegiatan sholat berjamaah sedikit di batasi, tetap boleh dilakukan akan tetapi harus menerapkan protokol kesehatan. Berbagai upaya dilakukan untuk melindungi setiap warga agar tidak terjangkit Covid-19. Aturan yang sudah dikeluarkan lembaga Kesehatan dunia WHO untuk melakukan promosi Kesehatan tidak terkecuali anak-anak (Kharisma, dkk, 2020).

Di wilayah Blitar terdapat beberapa masjid yang masih aktif melaksanakan kegiatan sholat berjamaah meskipun sedikit terganggu karena adanya pandemi. Pemerintah Kota Blitar memperbolehkan adanya kegiatan sholat berjamaah di Masjid akan tetapi harus tetap 
menerapkan protokol kesehatan. Salah satu cara untuk mencegah penyebaran virus Covid19 di masjid alah dengan menggunakan masker. Akan tetapi, masih terdapat jamaah yang belum memakai masker, dan jarak jarak sholat yang masih berdempetan (Machendrawaty dkk, 2020).

\section{MASALAH}

Himbauan untuk mengenakan masker dan memperhatikan protokol kesehatan saat beraktivitas di luar rumah masih diabaikan. Berdasarkan hasil studi awal yang dilakukan di Masjid Kota Blitar, masih ditemukan jamaah masjid yang tidak paham tentang pentingnya menggunakan masker untuk mencegah Covid-19, tidak disiplin mengenakan masker dengan benar, tidak sedikit pula yang bandel untuk tidak mengenakan masker. Di situasi dan kondisi saat ini, kesadaran seluruh masyarakat untuk patuh dan taat dalam menjalankan protokol kesehatan memiliki peranan yang signifikan, sehingga perlu ditekankan kepada seluruh masyarakat untuk mematuhi protocol Covid-19 agar mengurangi penyebaran virus di Masjid. Tujuan dari pengabdian ini adalah untuk mencegah dan memutus mata rantai penularan Covid-19 di Masjid Kota Blitar.

\section{METODE PELAKSANAAN}

Pengabdian pada Masyarakat yang diselenggarakan pada hari Jumat tanggal 11 Juni 2021 ini dilaksanakan dalam bentuk sosialisasi penggunaan masker sekaligus membagikan masker secara gratis sebanyak 100 masker kepada jamaah sholat Jumat di Masjid Kota Blitar. Adapun metode yang digunakan dalam pelaksanaan pengabdian ini adalah melalui edukasi kepada jamaah sholat Jumat di Masjid Kota Blitar untuk menghimbau pentingnya menggunakan masker. Kemudian dilakukan kegiatan pembagian masker kepada para jamaah sholat Jumat di Masjid Kota Blitar.

\section{HASIL DAN PEMBAHASAN}

Solusi permasalahan yang dapat ditawarkan untuk mengurangi resiko penyebaran Covid-19 di Kota Blitar adalah meningkatkan pengetahuan masyarakat terkait Covid-19 dan pencegahan penularannya melalui kegiatan sosialisasi. Kegiatan pengabdian dilaksanakan oleh tim yang terdiri dari dosen-dosen Universitas Islam Balitar, Blitar.

Kegiatan pengabdian masyarakat diawali dengan memberikan sosialisasi mengenai pentingnya menjaga kesehatan di tengah pandemi Covid-19 dan pencegahan penularannya. 
Setelah sosialisasi dilakukan pembagian masker kepada para jamaah sholat jumat di Masjid Kota Blitar.

Kegiatan pengabdian berupa program pemberian masker gratis kepada para jamaah sholat jumat sebanyak 100 buah telah dilaksanakan pada tanggal 11 Juni 2021 di Masjid Kota Blitar. Tujuan kegiatan ini adalah sebagai bentuk pengurangan resiko penyebaran Covid-19 yang merupakan ancaman kesehatan global pada saat ini. Kegiatan ini diterima dengan antusias oleh para jamaah sholat jumat.
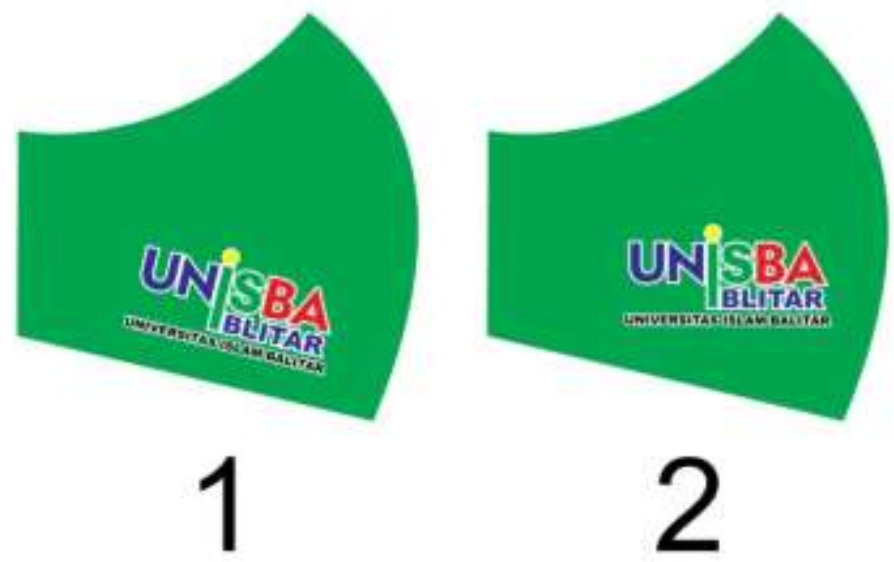

Gambar 1. Desain masker gratis

Kegiatan pengabdian melalui program masker gratis di masjid Kota Blitar tidak hanya berupa bagi masker gratis sebanyak 100 buah kepada jamaah sholat jumat utamanya jamaah yang tidak memakai masker. Pembagian masker gratis terutama diperuntukkan bagi jamaah tidak memakai masker sehingga kedepannya ketika akan melakukan kegiatan baik kegiatan ibadah maupun lainnya dapat menggunakan masker, khususnya bagi mereka yang memiliki anggota keluarga yang beresiko tinggi seperti balita, ibu hamil, lansia dan orang yang memiliki penyakit dapat terhindar dari virus ini. 


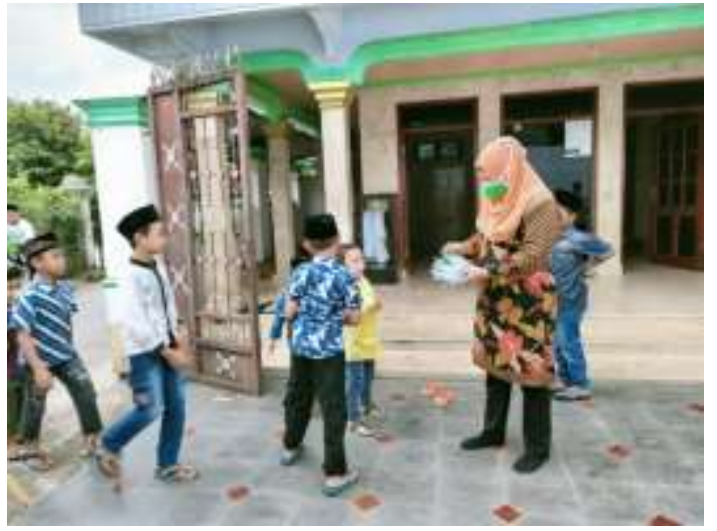

$\mathrm{a}$

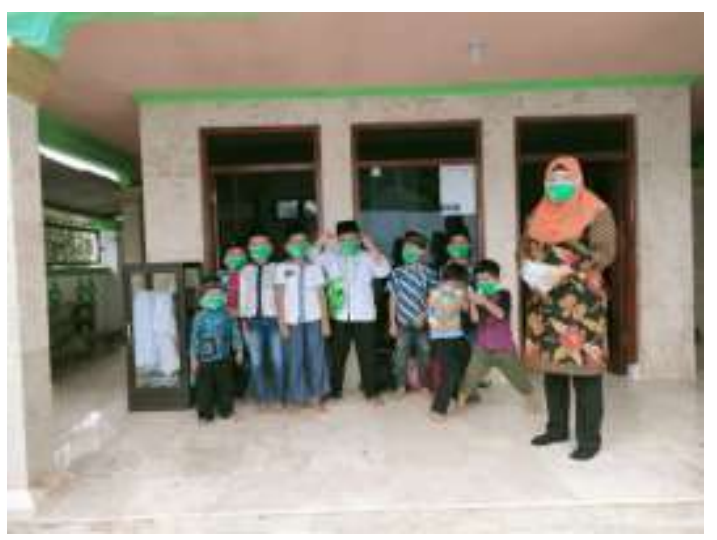

c

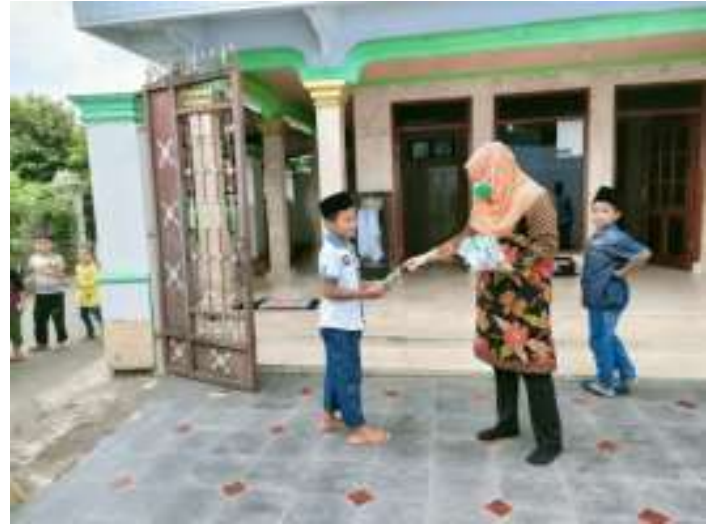

$\mathrm{b}$

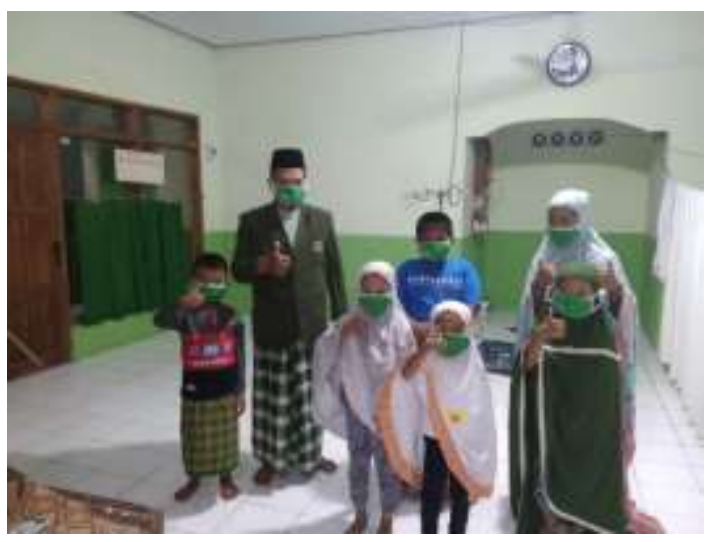

d

Gambar 2. Kegiatan pembagian masker gratis

Menggunakan masker merupakan salah satu upaya untuk meminimalisir penularan virus covid dan langkah ini sudah diwajibkan pemerintah pada 5 April 2020. Standar masker yang digunakan yaitu masker n-95 dan masker bedah, namun semenjak kasus virus ini merebak menyebabkan kelangkaan masker medis di Indonesia. Untuk memenuhi kebutuhan terhadap masker maka diberlakukan masker standar SNI (masker n-95 dan masker bedah) diperuntukkan oleh tenaga medis sedangkan masyarakat umum dianjurkan untuk menggunakan masker kain (Armiani, 2020).

\section{KESIMPULAN}

Kesimpulan yang dapat diperoleh dari pelaksanaan kegiatan pengabdian masyarakat ini adalah terjalinnya kerjasama antara institusi pendidikan dengan masyarakat Kota Blitar dalam upaya penanggulan Covid-19. Kemudian terlaksananya kegiatan sosialisasi 
pencegahan penularan covid-19 di Masjid Kota Blitar dan pemberian masker gratis sebanyak 100 buah kepada jamaah sholat jumat terutama bagi yang jamaah yang tidak menggunakan masker agar kedepannya ketika akan melakukan kegiatan baik kegiatan ibadah maupun lainnya dapat menggunakan masker.

\section{UCAPAN TERIMA KASIH}

Terimakasih kami sampaikan kepada Universitas Islam Balitar Blitar yang telah memberikan dana sehingga dapat terlaksananya kegiatan pengabdian kepada masyarakat ini. Kemudian tak lupa kami juga berterimakasih kepada peserta yang telah dengan senang hati mengikuti kegiatan pengabdian ini.

\section{DAFTAR PUSTAKA}

Armiani, S., Fajri, S. R., Sukri, A., \& Pidiawati, B. Y. (2020). Pelatihan pembuatan masker sebagai upaya antisipasi penyebaran covid-19 di Desa Anyar Kabupaten Lombok Utara. Jurnal Pengabdian UNDIKMA, 1(1).

ECDC. (2020). Using face masks in the community Reducing COVID-19 transmission from potentially asymptomatic or pre-symptomatic people through the use of face masks. April, 1-6.

Kemenkes RI (2020). Pedoman Pencegahan Dan Pengendalian Corona Virus Diseases (COVID-19). Direktorat Jenderal Pecegahan dan Pengendalian Penyakit. KMK No. HK. 01.07-MENKES413-2020 tentang Pedoman Pencegahan dan Pengendalian COVID19.

Kharisma, A., Achaddani, A. C., Ardelia, D., \& Dika, E. S. Partisipasi Mahasiswa Kkn Bmc Unnes 2020 Dalam Pencegahan Covid-19 Melalui Pembagian Masker Di Lingkungan Masyarakat.

Machendrawaty, N., Yuliani, Y., Setiawan, A. I., \& Yuningsih, Y. (2020). Optimalisasi fungsi mesjid di tengah pandemic Covid 19: Telaah syar'i, regulasi dan aplikasi. UIN Sunan Gunung Djati Bandung.

Yuliana (2020). Corona virus diseases (Covid-19); Sebuah Tinjauan Literatur. Wellness and Healthy Magazine Vol.2 No. 1.

\section{(c) (1)}

(C) 2021 by authors. Content on this article is licensed under a Creative Commons Attribution 4.0 International license. (http://creativecommons.org/licenses/by/4.0/). 